\title{
Investor Scale and Performance in Private Equity Investments
}

\author{
Alexander Dyck \\ Lukasz Pomorski ${ }^{1}$
}

November 2014

\begin{abstract}
We document that defined benefit pension plans with significant holdings in private equity (PE) earn substantially greater returns than plans with small holdings in both the 1990s and the 2000s. A one standard deviation increase in PE holdings is associated with $4 \%$ greater returns per year. Up to one third of this outperformance comes from lower costs that we link to economizing on costly intermediation by avoiding fund-of-funds and investing directly. The bulk of the outperformance comes from superior gross returns only partially explained by access and experience. We conjecture that larger PE investors have superior due diligence and ability to bridge information asymmetries in PE.
\end{abstract}

JEL classification: G11, G20, G23.

Keywords: private equity, alternative assets, pension funds, investment management, size, economies of scale

\footnotetext{
${ }^{1}$ Dyck is at the Rotman School of Management, University of Toronto (adyck@rotman.utoronto.ca); Pomorski is at AQR Capital Management, LLC (lpomorski@gmail.com). We thank Bernard Dumas (the editor), two anonymous referees, Keith Ambachtsheer, Rob Bauer, Dirk Broeders, Joe Chen, Susan Christoffersen, Martijn Cremers, Craig Doidge, Ming Dong, Chris Flynn, David Goldreich, Mike Heale, Uli Hege, Yael Hochberg, Greg Kadlec, Lisa Kramer, Stefan Lundbergh, Andrew Metrick, Terrie Miller, Narayan Naik, Ludovic Phalippou, Oleg Shibanov, Laurens Swinkels, Alan White, Kent Womack, and the participants of Rotman International Centre for Pension Management's 2010 Discussion Forum, 2011 European Winter Finance Conference, UC Davis Symposium on Financial Institutions and Intermediaries, York University Alternative Investments Conference, $5^{\text {th }}$ Conference on Professional Asset Management, 2011 Caesarea Center Academic Conference, Coller Institute of Private Equity conference, Western Finance Association conference, and seminars at the Bank of Canada, INSEAD, University of Toronto, Canada Pension Plan Investment Board, Melbourne Business School, and University of Michigan for many useful comments. We gratefully acknowledge the use of data from CEM Benchmarking, a Toronto-based global benchmarking firm, and the support of the Rotman International Centre for Pension Management. All errors are our own.
} 
Our knowledge of the economics of private equity $(\mathrm{PE})$ is based in large part on studies of limited partner (LP) investments of a typical investor in a private equity fund (e.g. Metrick and Yasuda (2007)). There are good reasons to go beyond such data to assess PE attractiveness for investors. Many PE investors do not restrict themselves to LP investing, but also invest through fund-of-funds, and invest directly or alongside general partners as a co-investment. The resulting cost differences arising from alternative uses of intermediation services could influence performance. Probably of more importance, PE investors differ in their skills in identifying and getting access to better performing partnerships, and in their ability and effort to monitor performance, potentially producing very different gross returns from their PE investments.

Variation in net returns across PE investors is particularly important if the deviations are not random, but rather are linked to specific investor characteristics. Lerner, Schoar and Wongunswai (2007), and Sensoy, Wang and Weisbach (2014) explore the potential importance of investor type, finding that endowments outperformed in the 1990s in venture capital fund investing, but that investor type does not predict returns in the 2000s. In this paper we focus on the scale of investment in $\mathrm{PE}$, and test whether this characteristic is associated with differences in returns.

The possibility of scale-related differences in performance has been sidestepped in much of the PE literature, in large part as a result of data availability. Studies that rely on the PE holdings of one investor (e.g. Metrick and Yasuda (2007), Robinson and Sensoy (2012)) cannot speak to potential scale related differences in performance. Likewise, studies of LP returns to fund investing (e.g. Kaplan and Schoar (2004), Phalippou and Gottschlag (2009)) cannot speak to potential gross return and cost differences across investors' PE portfolios of LP, fund-of-fund and internal investments.

To study potential scale-related differences in overall returns to PE investing, one needs data on $\mathrm{PE}$ portfolios in a sample that includes investors with very different PE holdings. 
Ideally, this sample will also hold constant investor type to get a clearer identification of a scale effect. We use precisely such data from a large international sample of defined benefit pension (DB) plans made available by CEM Benchmarking Inc. (CEM), a Toronto-based global benchmarking firm. The database includes 874 separate international plans over the years of 1990 to 2009 with significant cross-sectional and time series variation in the scale of their PE investing. At the end of our sample, plan assets are about US $\$ 5.5$ trillion, including $\$ 268$ billion in PE holdings. The largest investors in our sample allocate over $10 \%$ of their assets to PE, producing PE holdings of as much as $\$ 15-25$ billion.

Analysing the CEM data, we find that investors with substantial PE investments perform significantly better in PE than investors with small PE investments. A one standard deviation increase in PE holdings is associated with $4 \%$ greater returns, and implies that the largest quintile PE investors, with $\$ 6$ billion in $\mathrm{PE}$ on average at the end of the sample, have 7.4\% per year higher net returns (gross returns minus cost) than the smallest quintile PE investors. This relationship between investor scale in PE and PE performance is monotonic in PE holdings, robust, and consistent across geographies (e.g., US only, Canada only, Australia and Europe only). Importantly, the relationship between scale in PE investing and performance is economically and statistically significant across the 1990s and the 2000s, although the impact is somewhat lower in the 2000s with the more mature PE investing environment. While a positive size-performance relationship could reflect systematic differences in risk exposures between significant and small investors, additional tests suggest this is unlikely.

We explore the economic determinants of the impact of scale on performance. We hypothesize that investors that make larger PE investments rely less on costly intermediaries. We find that larger PE investors both limit the use of the most costly fund-of-funds and that some invest directly, avoiding intermediation fees completely (e.g., through co-investments). The largest quintile $\mathrm{PE}$ investors invest $10 \%$ of their portfolios through co-investments or direct 
investing. We also hypothesize and find evidence consistent with superior negotiating power of large investors, who have lower costs within each investment approach. Taken together, the differences in costs between larger and smaller investors in PE account for up to one third of larger investors' outperformance.

Such cost savings could come at the expense of more poorly targeted and executed investments. We find the reverse. Larger investors also have superior gross returns. Superior access to top performing PE partnerships, or experience of larger PE investors could potentially explain this outperformance. Proxies for these characteristics provide only modest explanatory power. We conjecture that the most likely explanation for the remaining superior return is that $\mathrm{PE}$ scale is associated with more information and information processing ability. While we have no direct measures to test this conjecture, it offers the simplest explanation for three facts we document: larger investors use fewer intermediation services; larger investors deliver superior gross returns in each PE investment approach (fund-of-funds, LP investing and direct investing) suggesting some common capability; and, we find a positive association between skill in internal investing (associated with larger investors) and subsequent performance in fund investing. Supportive evidence for this conjecture is also provided by a survey of limited partners by DaRin and Phalippou (2014) where scale of PE investing correlated with effort devoted to initial due diligence and ongoing monitoring.

We also consider the hypothesis of organizational diseconomies (e.g. Chen, Hong, Kubik and Stein (2004)) that predicts that scale will eventually reduce performance, as hierarchies emerge and discourage collection of relevant soft information. We find some evidence of concavity in the scale and performance relationship concentrated in the very largest $\mathrm{PE}$ investors and substantially beyond the typical scale of DB plans' PE holdings.

This finding that investor scale is of first order importance in predicting use of intermediation in $\mathrm{PE}$ and in performance builds on and extends prior work on the role of 
investor type (e.g. Lerner, Schoar and Wongsunwai (2007) and Sensoy, Wang and Weisbach (2014)). Focusing on one type of investor, and accessing their portfolio of investments, we find that scale of PE investing is associated with stronger returns, and that this remains important in the more competitive PE environment in the 2000s. Prior research using endowment data provided some indications that scale might be important (e.g. Lerner, Schoar, and Wang (2008)) but this impact was not emphasized. We analyse size in detail and provide economic explanations linked to scale such as the ability to economize on intermediation costs. Moreover, our results are based on substantially larger scale in PE investing, both as a result of including more recent data through 2009, which has accounted for the bulk of PE investing, but more importantly by focusing on DB plans whose scale of investing in PE dwarfs that of endowments.

Our results are distinct from investigations whether the scale of PE funds influences performance. The most recent studies from LP investing that cover our sample period (e.g. Harris, Jenkinson, and Kaplan (2013)) find no evidence of a relationship between fund size and performance. So if the only difference between large and small PE investors was the scale of the funds in which they invest, we would see no relationship between investor scale and performance. Our results suggest other factors are important.

The rest of the paper is organized as follows. Section I describes our data. Section II examines the impact of investor scale in PE on performance. Section III explores the economic determinants of the performance differences between significant and smaller PE investors.

I - Data

\section{I.1 Datasource}

To examine links between the scale of investment in $\mathrm{PE}$ and performance we use PE holdings, costs, and returns from an international sample of pension plans provided to us by CEM Benchmarking, Inc. (CEM), a Toronto-based global benchmarking firm. The data is based 
on survey responses of 874 distinct pension plans and spans the years 1990 to 2009 with 5,406 plan-year observations. Table I provides an overview. In the average sample year, we have 270 funds that account for $\$ 2.9$ trillion in assets under management (AUM), with the maximum of 368 plans per year and $\$ 5.5$ trillion in AUM. The average plan manages $\$ 10$ billion while the median plan size is $\$ 2.5$ billion, indicating positive skewness in size. PE holdings per year average $\$ 705$ million over the time period, growing to $\$ 1.4$ billion per year in the last 3 sample years. US plans (corporate plans) account for $57 \%$ (55\%) of our observations and include a greater fraction of the largest (smaller) plans.

Particular strengths of the CEM database are that it has performance data for the full PE portfolio (including LP investments, fund-of-fund investments, and direct investments) and that it reports returns separately by each of these approaches. To the best of our knowledge, ours is the first paper that breaks out data on PE holdings managed by internal managers for a large sample. ${ }^{2}$ Plans also report separately the gross returns and costs that produce net returns, and this reporting is subject to validation checks by the data provider. The cost data is based on the dollar amounts investors in our sample paid to managers (including base and performance fees) and the plan's activity-based allocation of fixed costs to that activity. ${ }^{3}$

Alongside these strengths are limitations. CEM performance data are internally reported annual returns by PE investment approach that boards use in assessing performance across all of their various investments. Returns are based on capital distributions from exited investments and on changes in audited net asset value (NAV) for remaining portfolio investments divided by

\footnotetext{
${ }^{2}$ Fang, Ivashina and Lerner (2014) explore performance differences between fund investing, direct and co-investing for a sample of 7 large investors.

${ }^{3}$ Survey participants are asked to include in external active management costs "All fees paid to third-party managers including investment management fees, manager-of-managers fees, performance-based fees, commitment fees and hidden fees netted from the returns" and "other internal and external costs that can be directly attributed to specific externally managed holdings." For example, CEM directs respondents in the following way: "the costs of a trading system used by both internal domestic stock and fixed income managers should be allocated to both internal domestic stock and fixed income investment cost based on an estimate of usage. A simpler and acceptable alternative allocation method is to allocate overhead costs based on relative direct head count." Instruction and Footnotes, 2009 US Defined Benefit Pension Fund Survey. http://www.cembenchmarking.com/Surveys/SurveyDownload.aspx
} 
invested capital (including new investments). Performance based on NAVs will understate performance when a program first begins. Lacking fund level data, we cannot control directly for vintage years effects or breakdown returns separately for venture and buyout fund programs.

Given these data limitations, the CEM performance data is less appropriate for assessments of absolute PE performance than studies that take advantage of fund-level cash flow information. At the same time, data on the overall PE portfolios is what is required to assess if there are different returns between larger and smaller PE investors, particularly because most investors do not limit themselves to LP investing. Moreover, in focusing on differences in returns between large and small investors we expect little impact from potential systematic biases in reporting (e.g. from NAVs or vintage years) that may come with CEM data. Such biases are likely to be widespread across PE investors and independent of investment scale and therefore will have a similar impact on returns for substantial and small PE investors. Where possible, we identify situations where potential biases (e.g., differential risk exposures) might depend upon scale and conduct additional tests to ascertain their potential importance.

We use the provided data as given, with the following changes. Holdings are originally provided in each plan's local currency. We express asset holdings in real (2009) US dollars using interbank exchange rates as of December 31 of each sample year and the CPI deflator from St. Louis Fed. We use returns as reported. ${ }^{4}$ We winsorize cost and return data at the $1^{\text {st }}$ and the $99^{\text {th }}$ percentile to avoid results being driven by a few extreme observations that remain even after the CEM vetting process. For each plan we have an ID, country or region of domicile (e.g., US, Canada, etc.), ownership (corporate, public, other ${ }^{5}$ ), the fraction of liabilities that are due

\footnotetext{
${ }^{4}$ Results are substantially similar if we also express returns in dollar terms. Our baseline results are identical if nominal holdings size is used (because the CPI adjustment becomes additive when we use log size and is then subsumed in year fixed effects).

${ }^{5}$ The 'other' category accounts for 600 plan-year observations and includes union pension plans, insurance funds, and a few endowments and sovereign wealth funds. Results are robust to excluding this category.
} 
to current retirees, etc. Our data provider requires us to preserve plan anonymity and does not allow us to match data with alternative data sets.

The dataset is an unbalanced panel over the 1990-2009 period. The mean (median) length of time a plan with a given ID in the sample is 6.2 (4) years. The relatively short duration in the dataset arises from the increasing number of participants in the benchmarking service over time, ${ }^{6}$ from the fact that CEM assigns new identifiers to plans following a substantial change in the structure of plan membership (e.g. a merger), and from other idiosyncratic reasons that lead plans to cease to participate in the benchmarking service.

The scale of investment in PE differs significantly across plans. Measured over the whole sample, the median plan invests $\$ 114$ million into PE, while the largest plans average $\$ 3$ billion in PE investments. We also present data for the last three years in the sample to account for the time trends in $\mathrm{PE}$ investments. ${ }^{7}$ In the most recent years, the median $\mathrm{PE}$ investment doubles to $\$ 242$ million, with the $1^{\text {st }}$ quintile PE investors investing $\$ 27$ million and the $5^{\text {th }}$ quintile $\$ 5.7$ billion. More than 8 in 10 invest in $\mathrm{PE}$ in the largest plan size quintile, while only 2 of 10 of the smallest size quintile plans invest.

\section{I.2 Coverage, Representativeness and Potential Biases}

As with any new data source, there are questions about its coverage, representativeness, and potential biases. The CEM database has been used in previous papers including French's (2008) presidential address on the costs of active investing, Bauer, Cremers and Frehen's (2011) analysis of US plans' investments in US equities, Dyck, Lins, and Pomorski (2013) study of Canadian and US plans investments in foreign equities, and Andonov, Bauer and Cremers (2012) study of overall plan performance.

\footnotetext{
${ }^{6}$ For example, 168 of the 874 plans appear in the data only in 2006 or later, so these plans can have at most 4 observations. The average plan appears in $57 \%$ of years following its addition year.

${ }^{7}$ Harris, Jenkinson, and Kaplan (2013) report $\$ 794$ billion in PE commitments in 2005-2008, compared to $\$ 668$ billion in the previous decade of $1996-2004$, and $\$ 148$ bn in the previous 15 years for $1980-1995$.
} 
The database is particularly strong in its coverage of very large plans, aided by the inclusion of international plans. The sample includes on average (max) 26 (104) plans with more than $\$ 10$ bn a year, 29 (52) plans with more than $\$ 25$ bn a year, and 5 (11) plans larger than $\$ 100$ billion per year. While the cost of the benchmarking service is moderate, it is more easily covered by larger plans whose sponsors are more likely to demand the benchmarking as part of their governance of the plan. Our data provider allowed us to compare the list of plans covered to the list of top 1,000 US pension plans published by the trade journal 'Pensions and Investments' for 2007. The CEM database includes at least 215 plans in the top 1000, with a higher percentage of CEM plans among the largest plans (172 plans in the top 500, 110 in the top 200 and 57 plans in the top 100). Testimonials on the CEM website and publicly available statements show that the service is used by many of the largest plans in the world. ${ }^{8}$ We have particularly strong representation from US and Canadian pension plans: at the end of the sample US plans account for approximately $45 \%$ of assets in US defined benefit pension plans and Canadian plans account for $90 \%$ of assets in Canadian plans.

While the database is quite comprehensive, it does not cover the universe of plans, raising questions whether the omitted plans might have different characteristics, and whether those characteristics influence performance. For the US, we can identify omitted plans and compare their characteristics with plans that report to CEM. We compared asset allocation of the US plans in the CEM database with asset allocation in the Pensions and Investments 2007 top 200 US funds list (the sample for which they report asset allocation) and found statistically indistinguishable and economically small differences across the two samples. We next looked at performance of corporate pension plans of publicly-traded US firms that are required to report net plan returns in their annual statements and which Compustat covers since 1996. The time

\footnotetext{
${ }^{8}$ Publicly available information from the CEM website and plan public disclosures show that the participants include the large American plans CalPERS (\$199B in assets according to 2009 Pensions and Investment's Databook) and CalSTRS (\$130B), the large Canadian plans CPPIB $(\$ 122 \mathrm{~B})$ and Ontario Teachers $(\$ 92 \mathrm{~B})$, and the large European plans PFZM/PGGM (\$124B) and ABP/APG $(\$ 300 B)$.
} 
series averages of the equally-weighted cross sectional average (median) returns of such plans in the CEM database are $7.3 \%(7.0 \%)$ (CEM has on average 87 US corporate plans per year with the maximum of 123). There are many more plans reported by Compustat firms (2137 on average), the bulk of which are substantially smaller. The average return of these plans is $6.6 \%$ for the whole sample, $6.9 \%$ for plans at least as large as the smallest CEM plan $(\$ 25 \mathrm{~m})$, and $7.4 \%$ for the largest 200 corporate plans. Our interpretation of these comparisons is that our US sample is comparable with the population of plans in Compustat, but skewed towards larger plans. We do not have population data and cannot carry out similar analyses for non-US plans. However, the Canadian data is particularly comprehensive (in 2009 for example we capture $90 \%$ of all Canadian defined benefit assets), so there are fewer ex ante concerns of bias here.

Another potential bias would be if firms came in and out of the database based on their performance. Plans that no longer report do remain in the database. We also compared the net returns minus benchmark returns of new plans (plans that enter the database in year $t$ ) and plans that have reported in the immediately preceding year (have reports in both year $t$ and year $t$-1). The difference is essentially zero $(-0.002 \%)$. Similarly, the difference in the performance of plans that skip a year (enter the database before year $t$ and report in year $t$, but not in year $t-1$ ) and plans that continue reporting (report in both years $t$ and $t-1$ ) is tiny ($0.05 \%)$. These results suggest it is unlikely that plans strategically report only in years when their performance is superior. There is no bias in the reporting of PE holdings and performance, as plans report the holdings and returns to their complete PE portfolio.

\section{II $\quad$ Size and Performance in Private Equity}

\section{II.1 Descriptive Data}

To begin our exploration of a possible relationship between the scale of investment in $\mathrm{PE}$ and performance we turn to the descriptive statistics of Table I. This data is based on the full 
time period of 1990-2009. To limit the effect of any particular year, we sort plans into quintiles in each year based on the previous year's holdings (e.g., 1990 holdings for 1991 data), and report the time series averages. In the far right column we report differences between the largest and the smallest PE investor quintiles. Given the time series pattern of increasing holdings in PE, the reported average holding size is unlikely to be representative of any specific year. As one way to address this limitation, we also report at the bottom of the panel just the final three years of the sample, when CEM had the most plans and more plans were likely to have some PE investments.

These data provide early indications of superior returns for substantial compared to the smallest PE investors. Compared to small investors, larger investors have on average a superior gross return of $8.8 \%$ per year, lower costs of 201 basis points per year, and superior net returns of $10.8 \%$ per year, with the differences in gross and net returns monotonic in size quintiles. At the end of our sample period (2007-2009), a more challenging period for PE, significant differences remain with a $5.9 \%$ per year greater return for larger investors. We produce a simple measure of 'excess' net returns by subtracting S\&P 500 returns from annual reported net returns, lagging index returns by one quarter to reflect an expected time lag in PE reporting. ${ }^{9}$ This lowers mean returns to PE investing to $2.6 \%$ per year but has no effect on the differences across investors in returns. Any corrections for exposure to systematic risk that are common to small and large PE investors drop out when we compute performance differences.

A more important concern is potential differences in the risk profiles of PE portfolios of larger and smaller investors. Below we address this possibility by introducing controls for investment approach, for potential differences in the types of funds between large and small PE investors, and for exposure to risk factors. Here, as a more crude way to address concerns about differential risk exposure possible with summary statistics, we subtract from net returns a

\footnotetext{
${ }^{9}$ We have similar statistical and economic significance regardless of whether we lag index returns or not.
} 
benchmark PE return set by plan sponsors (who have full information on their portfolio). If set properly, these benchmarks should capture important cross-sectional and time series differences across portfolios. The data suggests this is a more demanding hurdle than S\&P500 returns, with mean net returns minus benchmark of $-1.7 \%$ per year (versus $+2.6 \%$ for S\&P500). More importantly, the resulting performance difference between large and small plans is $9.7 \%$, substantially the same as without benchmarks.

These summary statistics, while suggestive, are not sufficient to establish a link between size and performance. Domicile (US or non-US) and sponsorship (corporate versus public) also correlate with size and could be driving the relationship, factors other than size may influence returns, and there are better ways to address risk. We address these issues in a regression framework.

\section{II.2. Size and Performance in Private Equity}

In Table II we use multivariate regressions of performance on scale of PE investment exploiting simultaneously cross-sectional and time-series variation in size in our sample. In all these regressions we define 'investment scale' as the logarithm of previous year dollar PE holdings. In our primary regressions the dependent variable is the net return (the difference between gross returns and costs).

Having greater dollars invested in PE predicts stronger performance. A simple univariate regression (untabulated) produces a positive and significant coefficient on lag log PE holdings of 1.096 (t-stat of 4.39). More compelling are regressions with controls in Table II. In (1) we arrive at a similar result with controls for sponsorship (corporate or not) and domicile (US or not) that covary with size. In (2) we redefine the performance measure as 'excess' net returns by subtracting the S\&P 500 benchmark return, producing again a statistically significant positive coefficient on lag log PE holdings. 
Our preferred baseline regression is (3) that uses net returns as the dependent variable, the controls in (1), and year fixed effects. Year fixed effects are also equivalent to a common benchmark on returns, and capture in a crude way the impact of vintage years. There may be correlation of residuals within a plan across years and within a year across plans. To account for the former, we cluster errors at the plan level. To account for the letter, we follow Petersen (2009), who in settings like ours (a large number of plans per year, but relatively few years per plan) recommends clustering by plan and including year fixed effects. ${ }^{10}$

The regression produces a statistically significant impact of lagged scale on performance (t-stat of 6.8) that is economically large. We compute a conventional one standard deviation change in log holdings (equivalent to $\$ 1.9$ billion) and the implied change in performance due to a move from the median level of holdings of the smallest plans (Q1; 20\% of plans with the smallest overall size) to the median holdings of the largest plans (Q5). By either measure, the impact of size is substantial: a one standard deviation change moves performance by $4 \%$ and the move from small to large improves net PE returns by $7.4 \%$ p.a. To put these magnitudes in perspective, the mean net return in PE in Table I is $9.6 \% .{ }^{11}$

In light of recent evidence that with the maturing of the PE industry investor type no longer predicts PE returns in the 2000s (Sensoy, Wang and Weisbach (2014)), we explore whether the maturing of the PE industry has a similar impact on the return to PE scale. In (4) and (5) we show the results separately for the 1990s and for the 2000s. The impact of investor scale on performance remains statistically significant and economically important in both periods, albeit reduced in magnitude in the 2000s. The implied performance improvement with a

\footnotetext{
10 The results are similarly strong when we double cluster on both year and plan: For example, the resulting tstatistic on size in regression (3) described below is 3.43 ; the only qualitative change is that the non-US dummy becomes insignificant with double clustering. Another approach to address this issue is to use the Fama-McBeth method, something we do in (8).

11 Results are robust across geography. In unreported regressions, we find a strong impact of size in regressions estimated separately for US plans, Canadian plans and other geographies (Europe, Australia, and New Zealand).
} 
one standard deviation change in scale is $5 \%$ in the 1990 s and is less, but remains economically significant at $3.5 \%$ per year in the 2000 s.

To assess the robustness of this finding of a strong link between PE investment scale and performance, we consider alternative explanations. If larger investors have invested in PE for a longer period and therefore have a portfolio of older investments than smaller PE investors, then their outperformance could be driven by the well-known j-curve effect - returns are lower in early years while capital is deployed only to yield returns later in the fund life. In all of our regressions the first year in the dataset with $\mathrm{PE}$ performance is ignored, as we include lagged PE holdings as the main independent variable, allaying to some extent the $\mathrm{j}$-curve concern. ${ }^{12}$ In (6) we introduce a variable to capture funds likely to be early in their j-curve, and find the estimated impact of fund scale on PE performance remains statistically and economically important, with a slightly higher estimate. The variable is the ratio of $\mathrm{PE}$ holdings to the assets used to compute fees, restricting attention to plans that have a ratio less than one (where there is a clearer interpretation as a proxy for the position on the $\mathrm{j}$-curve).

Larger investors could also assign a larger weight on buyout than venture funds, and if buyouts had higher returns, then this portfolio mix might be driving the size-return relationship. Such a tilt is more likely to the extent that large buyout funds are inaccessible to smaller first and second quintile size PE investors (e.g. if GPs impose a minimum investment scale), and if large PE investors stay away from smaller funds to limit the number of PE investments in their portfolio. If persistent differences in portfolios were the dominant factor driving returns, then larger investors should earn higher relative returns in the 2000s when buyouts clearly outperformed venture (e.g. see results reported in Harris, Jenkinson, and Kaplan (2013)). Contrary to this prediction, as reported earlier, the impact of scale is less in the 2000s (5) than in the 1990s (4). As a further test, we construct a measure of the difference between the

\footnotetext{
${ }^{12}$ In unreported regression, we confirm the results are robust to excluding additional early years in the dataset.
} 
performance of mega funds and small cap funds and interact this with our measure of $\mathrm{PE}$ investment scale in (7). If large investors outperformance comes exclusively from years where mega cap partnerships outperform small cap PE partnerships, this variable will load positively and lag holdings will be rendered insignificant. This interaction term is positive and significant but does not drive our result, as PE scale remains statistically significant and economically important. This test uses Preqin data on the returns to mega cap and small cap PE funds, which is available since $2001 .^{13}$

Finally, results could be driven by the impact of particularly good vintage years if large $\mathrm{PE}$ investors fortuitously overweighted $\mathrm{PE}$ in such years. Inconsistent with such behavior driving our result, returns are substantially the same in (8) when we equal weight each year following a Fama-MacBeth approach: regress performance on lag size in each sample year and then average the time series of estimates for the 19 years of data. As a further test, in (9) we exclude peak performance years associated with the strongest vintage years. We identify as strong buyout vintage years those that are one standard deviation above the mean based on Public Market Equivalent ratios (PMEs) reported in Harris et al. (2013). We exclude years 4 through 6 following these vintage years, as these are the years that account for the bulk of distributions. We continue to find a significant return to scale with only a slightly smaller economic magnitude.

Finally, in (10) we introduce plan fixed effects to estimate the effect of scale on performance using solely the within-plan variation in scale. ${ }^{14}$ The fixed effect captures the impact of any unobserved and long-standing plan-specific characteristic. The results are unchanged, PE investing scale has a sizable impact on performance.

\footnotetext{
13 The performance data is based on an index of quarterly returns for funds of different scales, with the percentage change in quarter $=[(\mathrm{NAV}$ at quarter end + distribution during quarter $) /(\mathrm{NAV}$ at quarter start + call-ups during quarter)] -1 .

${ }^{14}$ We have a number of plans with dramatic changes in scale over the sample period. For each plan with at least 3 observations we computed the difference between the maximum and the minimum PE allocation. For the median (average) plan, the difference between the two extremes, standardized by that plan's median allocation, is 2.3 (3.1).
} 


\section{II.2.1 Differences in Risk Exposures}

Interpretation of these results would be different if those investors with larger $\mathrm{PE}$ holdings took on significantly more risk. As noted earlier, any risk exposure common for all PE investors would not influence the estimated differences in returns. One source of such risk is the share of the portfolio in venture, which other studies have identified as riskier relative to buyouts. ${ }^{15}$ Inconsistent with a risk explanation, in our sample smaller PE investors have a greater relative share of venture. ${ }^{16}$ More generally, the magnitude of the performance differences and the robustness of the results across years make a risk explanation less likely, but does not rule out this possibility. Consequently, in Table III we conduct some standard asset pricing tests to see if including accepted risk factors affects estimates of the scale impact on returns. An important qualification is that these tests have limited power: using lag size limits us to 19 annual return observations. We cannot run regressions at the level of the plan level as the median number of observations per plan is 4 and including factors reduces degrees of freedom.

To maximize the number of observations we sort plans on prior year's PE holdings and construct a portfolio long in large PE investors (largest quintile) and short in small PE investors (smallest quintile). We include factor returns lagged one quarter to reflect an expected time lag in PE reporting (results are similar if we include instead contemporaneous and one year lags). In (1) we use the CAPM with the usual CRSP-based market portfolio while in (2) and (3) we follow Harris et al. (2013) and use the Russell 2000 and Russell 2000 Value indices, recognizing that the typical PE portfolio is tilted toward smaller companies and value companies. There is some indication that the larger investors' portfolios may have higher betas in the significant coefficient on the CRSP factor in (1) and the Russell 2000 value factor in (3). More importantly,

\footnotetext{
${ }^{15}$ Cochrane (2005), Drissen, Lin, and Phalippou (2011), and Korteweg and Sorensen (2010) find VC betas of 2.0, 2.7 and 2.5. In contrast, Drissen, Lin, and Phalippou (2011) and Franzoni, Nowak, and Phalippou (2011) report LBO beta estimates of about 1.3 and Jegadeesh, Kraussl, and Pollet (2011) find a beta of close to one.

${ }^{16}$ This is based on a subsample of funds that broke down holdings by venture and buyout for a limited number of years. In this subsample, $\mathrm{VC}$ holdings as a percentage of total PE holdings are largest in the smallest size quintile and are monotonic with size quintiles.
} 
even with this small number of data points we estimate a large and significant alpha on the long-short portfolio across all specifications, varying from $8 \%$ per year to $11 \%$. In (4) we estimate the Fama-French three factor model, producing similar results. In (5) we include both the market return and the difference in returns between mega and small PE partnerships to control for the previously discussed possibility that large investors disproportionately invest in mega funds. Again, we find economically and statistically significant alphas.

Finally, we take advantage of the fact that plans use benchmarks selected by plan overseers to monitor and evaluate the performance of the managers they hire. Inspection of the benchmarks suggests they are tailored to characteristics of the PE portfolios. For example, they vary by geography, some plans use levered equity as a benchmark, others use broader indices such as Russell 2000. ${ }^{17}$ Any gaming of these PE benchmarks, we expect, would work against us as it would be more likely in the smaller pension plans with less resources to devote to oversight. In unreported regressions, we estimate our baseline specification after subtracting benchmark returns from net returns and find identical results that a one standard deviation increase in PE scale is estimated to bring $4 \%$ per year greater returns (t-stat 7.49).

\section{What Economic Factors Drive Larger Investors' Superior PE Performance?}

\section{III.1 - Organizational Diseconomies Hypothesis}

Some theories suggest investment scale should hurt rather than help performance due to organizational diseconomies arising from hierarchy costs. In Stein's (2002) articulation of the problem, also discussed in Chen, Hong, Kubik and Stein (2004), diseconomies come from lower incentives to gather accurate information that arise in hierarchies that separate information gatherers from ultimate decision makers. This model may have particular relevance for PE, where soft information is thought to be at the heart of the investment process.

\footnotetext{
${ }_{17}$ Unfortunately, it is difficult to do much more with the benchmark descriptions, as many plans just list benchmark as 'custom', providing no additional information.
} 
The log-linear regressions from the previous section reject this hypothesis of organizational diseconomies. We tested the functional form using more flexible specifications, including squared terms, squared and cubic terms, and replacing the lagged log PE scale with dummy variables for quintiles of lag PE size, with our usual controls. We present these results graphically in Figure 1. Since scale is heavily skewed, we plot the regressions against the log of scale, ranging from $\$ 3$ million to $\$ 25$ billion (highest PE investment in the data). The squared and cubic terms are never statistically significant, but including them does affect predicted performance at very high levels of PE investment. Allowing for higher order terms, and looking at the predicted performance associated with size quintiles, suggests that the scale-performance relationship flattens (e.g. there is no statistically significant difference between the $4^{\text {th }}$ and $5^{\text {th }}$ size quintiles). Extrapolating the data beyond the scale of almost all funds, the squared specification suggests a turning point at about $\$ 34$ billion, and the turning point in the cubic specification is $\$ 11$ billion. While the eventual decline is in line with our economic intuition, the predominant fact that needs to be explained for the vast majority of our sample remains how larger investors are able to improve their performance.

\section{III.2 - Why do Larger Investors Generate Greater Returns: The Importance of Cost Savings}

A potential benefit of scale is the reduction in intermediation costs. The typical investment approach in alternatives is an LP position in an externally managed fund that historically has had a ' 2 and 20 ' fee structure that reflects the fees on committed capital and the percentage of the carried interest that goes to the GP (e.g. Metrick and Yasuda (2010)). A potentially less costly alternative to the typical externally managed fund is to establish internal capability and make investments, either co-investing alongside GPs or investing directly on one's own. There is a growing body of anecdotal evidence that internal investing is important 
for some large plans, ${ }^{18}$ and some survey evidence that size correlates strongly with co-investment invitations (e.g. DaRin and Phalippou (2014)). However, there is a paucity of empirical studies of its extent and importance. Fang, Ivashina and Lerner (2014) provide a study of its use by 7 large institutions, but we are aware of no existing research on how widespread this practice is and how it affects performance.

Larger PE investors have a comparative advantage in investing directly. There is a significant fixed cost component in building a capability to invest directly, either as a coinvestor or on one's own. These costs arise from building an IT backbone to monitor investment opportunities and a human resource capacity to attract and retain the requisite talent. With fixed costs, unit costs are lower for plans with a larger expected volume of transactions.

Another difference in approach that can be linked to scale is the necessity of using a fund-of-funds investment approach. Fund-of-funds is clearly a more costly approach to PE than LP investing as funds-of-funds layer on additional fees over and above those charged by GPs. This approach is particularly attractive for plans with intended PE investments that do not meet the minimum LP investment levels demanded by GPs, or cannot afford the people and resources to ex ante choose and ex post monitor and optimize their LP investments and therefore find it helpful to access and pay for this intermediation. Plans with scale in PE, in contrast, can more easily meet minimum investment sizes and thus are not forced to use fundsof-funds to access specific PE partnerships.

We test for the importance of these hypothesized comparative advantages of larger plans by first identifying cost differences investors report for different implementation approaches and then exploring the likelihood of using a given approach as a function of size. As noted above, in addition to overall net returns to PE investing, plans report costs and gross returns separately

\footnotetext{
${ }^{18}$ Large Canadian pension plans in particular have used this channel, as described in the annual reports of Ontario Teachers, OMERS, and Canada Pension Plan Investment Board, an HBS case study (case \#9-809-073), and "Maple Revolutionaries," the Economist, March 3, 2012.
} 
to CEM, and CEM performs some validation tests on this reporting. ${ }^{19}$ It is likely the reported costs and gross returns have more noise than overall returns given potential inconsistencies across GPs in how they report to their LPs, but we have no reason to believe that such noise will be related with the scale of PE investing.

Table IV Panel A provides summary statistics on costs; given time trends in costs and more observations in the final years of our sample, they are based on the last three years of the sample. Fund-of-funds is clearly the most expensive approach with annual reported costs of 694 bps, LP investing is about half as expensive at $351 \mathrm{bps}$, and internal management is about one twentieth the fund-of-funds cost at just 35 bps. Panel B shows a negative correlation of investor scale in PE and use of funds-of-funds. We find that the smallest quintile plans invest 21 percentage points more of their PE portfolio using this approach than the largest quintile plans (p-value $<0.01)$, and fund-of-funds investments account for almost half of all holdings. ${ }^{20}$

The summary statistics also show that the largest PE investors are most likely to use internal investing and have the biggest percentage of their PE portfolio in this approach. For the largest plans, internal holdings represent $10 \%$ of all $\mathrm{PE}$ holdings. Using finer size classifications, the difference becomes even more pronounced. For top decile investors, $28 \%$ their PE holdings are internal. Given the mean size of top quintile (top decile) investments in PE in these years of $\$ 5.7$ bn ( $\$ 9.1 \mathrm{bn})$, this implies $\$ 570$ million $(\$ 2.5 \mathrm{bn})$ are invested internally in these plans. Untabulated regression evidence lines up with the summary statistics. The largest size quintile allocation to internal is 11 percentage points higher than that of the smallest plans (p-value $<0.01$ ), in line with the summary statistics. Suggestive of the scale needed for internal

\footnotetext{
${ }^{19}$ Where CEM has significant concerns about reported costs that they are unable to address after correspondence with reporting plans, they introduce default PE costs. That is, CEM replaced reported costs for these plans with default costs that they calculated. We think this reduces the noise in the data. At the same time, if this is inaccurate this could affect our results. We therefore asked for and were provided a list of plan identifiers where default costs were used. We re-examined our findings excluding these observations and found that they had no quantitative or qualitative impact on these results, or those reported previously in earlier tables.

${ }^{20}$ Based on untabulated regression of the percentage of assets in fund-of-funds on size quintile dummies, with controls for the domicile, corporate status, and year fixed effects.
} 
investing, the largest plans' allocation to internal also exceeds that of the $4^{\text {th }}$ quintile by 6 percentage points $(\mathrm{p}$-value $<0.05){ }^{21}$

An alternative to lower intermediation costs that may explain how scale influences costs is superior negotiating power with external managers. Larger investors are more likely to be pivotal in the formation and/or successful closing of a fund. They can most easily put up the capital for a major position and have a fuller range of options to go elsewhere with their investments. To try to identify the potential impact of negotiating power, as opposed to cost savings from economizing on costly intermediation, we now examine the impact of scale on costs by focusing separately on fund-of-funds, LP, and internal investments.

The cleanest test for the negotiating power hypothesis comes in examining fund-of-funds PE investments. Both large and small investors can access these funds offered by external managers, with the potential for larger investors to negotiate better terms. We also expect negotiating power in LP investments, as larger investors may be looked on more favourably than smaller investors and could be given preferential terms. DaRin and Phalippou (2014) report in their survey that $99 \%$ or more of large LPs $\left(75^{\text {th }}\right.$ percentile $)$ receive both side letters and 'most preferred nation' clauses in their contracts, whereas smaller LPs $\left(25^{\text {th }}\right.$ percentile) receive neither. At the same time, we acknowledge another reason for size-related cost differences in LP investments that could come from larger investors investing in different size funds that have different costs (e.g. large buyout versus small buyout) that we cannot observe directly. Finally, size-related differences are unlikely for direct investing as this approach is limited to the largest investors.

In Table $\mathrm{V}$ model (1) we test whether scale in funds-of-funds affects costs in funds-offunds, continuing to control for corporate status, domicile, and year fixed effects. The negative

\footnotetext{
${ }^{21}$ Based on untabulated regressions of percentage internally managed on size quintile dummies, with controls for domicile, corporate status, and year fixed effects.
} 
and significant coefficient on scale is economically significant, implying 211 bps lower costs in fund-of-funds for those making top quintile fund-of-funds investments (a 30\% cost reduction from mean costs at the end of the sample period). This suggests negotiating power plays an important role in the reported cost savings.

In LP investments in (2) we also find a negative and significant coefficient on scale that implies that relative to first quintile plans, $5^{\text {th }}$ quintile plans enjoy cost savings of $112 \mathrm{bps}$. This is consistent with negotiating power, but could also reflect differences between larger and smaller investors in the cost structures of their LP investments. In (3) we examine costs for internally managed $\mathrm{PE}$ and, not surprisingly, the scale coefficient is close to zero and insignificant.

To wrap up this section, we size up the cost savings coming from both less costly intermediation and negotiating power. In (4) we use indicator variables for size quintiles based on lag holdings. Using quintiles we find cost savings for larger investors compared to the smallest quintile investors of a sizable and strongly significant 281 bps. Costs are monotonic with investor scale, with second through fourth quintile investors having costs 144 bps, 65 bps and 62 bps greater than the largest PE investors (the omitted category). In (5) we use a log linear specification and the coefficient of -44.7 on scale implies that larger PE investors have lower costs of 180 bps. Thus we find cost savings are an important part of the performance difference, but do not explain all of the performance gain, accounting for between one quarter (using the log linear specification) and one third (using size quintiles) of the $7.4 \%$ superior return we found in Table II.

We attempt to provide a decomposition of the cost savings coming from lower cost intermediation and from negotiating power in (6) by repeating this test including the fraction of the portfolio that uses more costly intermediation approaches of fund-of-funds and LP investing. The positive and significant coefficient on scale in (6) is consistent with scale-related savings 
over-and-above those coming from differences in the use of costly intermediation. Comparing the coefficients in (5) and (6) suggests larger plans save 145 bps in costs controlling for differences in their use of costly intermediation, which reflects a combination of negotiating power and potentially differences in the types of LP funds they invest in.

\section{III.3 - Explaining Superior Gross Returns for Larger PE Investors}

In addition to cost savings we find superior gross returns for larger investors. This is made clear in Table VI. In (1) we find that the scale of investment in PE is associated with much stronger annual gross returns, controlling for corporate status, non-US plans, and year fixed effects. The implied economic effect associated with a one standard deviation change in plan scale is $3 \%$ per year. In an untabulated specification that uses quintiles rather than log holdings we obtain even greater estimates, and with outperformance lowering monotonically with investor scale and ending up with no statistically significant difference in gross returns between large (quintile 4) and the largest investors (quintile 5). Column (2) shows the positive and significant coefficient on scale is not an artifact of differences in the approaches to PE, as including controls for the $\%$ of investments using fund-of-funds and $\%$ internally managed has no appreciable impact on the scale coefficient. This is not surprising in light of the fact that in additional untabulated tests we find no significant difference in gross returns across these different investment approaches. ${ }^{22}$

\section{III.3.1 Superior Access and Experience of Larger PE investors}

To explain past findings of differences in returns, the literature has focused on three explanations: better access to the best performing PE partnerships; more experience in PE; and/or better timing (e.g. Lerner, Schoar and Wangsonwai (2007)). With more recent findings

\footnotetext{
${ }^{22}$ In unreported regressions, we test for differences in gross returns across investment approaches of fund-of-funds, LP, and internal holdings where we treat them as separate observations (i.e., a given plan may contribute as many as three observations in each year) and regress them on indicators for each approach, with and without controls for corporate status and domicile, as well as year and plan fixed effects. In all cases, the investment approach indicators are insignificant.
} 
of no differences in returns across types outside of VC investing in the 1990s (Sensoy, Wang and Weisbach (2014)), the importance of access and experience is more open to doubt for limited partners in buyouts and in the 2000s. Nonetheless, we introduce some proxies to capture access and experience that are possible with our data, and see if their inclusion substantially reduces or eliminates the size performance relationship.

One interpretation of access is that it is a fixed effect associated with a pension plan, with some plans having attributes that make them attractive to better performing PE general partners. If this is the case, in a regression with plan fixed effects the coefficient on size captures how performance changes as investors increase in scale, keeping such preferential access constant. We explore this in (3), and continue to find a strong coefficient on scale suggesting access defined this way is not driving all of the returns. This is an admittedly weak proxy, as access could derive from past PE investing rather than from plan characteristics.

In (4) we introduce two alternative proxies for access and experience. To proxy for experience in the asset class we use the fraction of prior years in the database in which the plan had PE holdings. We also introduce a dummy variable indicating that a given pension plans' $\mathrm{PE}$ returns were in the top quartile last period, which is another way to capture preferential access. ${ }^{23}$ We find positive coefficients on these proxies, with statistical significance on the access proxy. More importantly, by comparing the coefficient on lag log holdings without the proxies for access and experience (1), and with the proxies (4), we have an indication of the importance of access and experience for these results. The estimated impact of investing scale is reduced by only about $10 \%$.

We also explored the potential impact of timing on these return differences between large and small PE investors. We approximate the lower bound on contributions by comparing

\footnotetext{
${ }^{23}$ This measure might also reflect autocorrelation in returns from staleness in NAV calculations. To address this possibility we reran the specification using a two period lag for top quartile plan returns, yielding similar results.
} 
holdings relative to lagged PE holdings multiplied by reported returns (we do not have separate data on distributions and contributions). If timing contributes to performance, there should be systematic differences in contributions across PE holding scale related to observable conditions in markets. Prior papers have focused on conditions in debt markets (e.g. the high-yield spread or TED spread), in equity markets (e.g. the $\mathrm{P} / \mathrm{D}$ ratio), and in the volume of contributions to PE. In unreported regressions we found that large funds have relatively lower contributions in years with high aggregate PE commitments, but found no significant relationship between contributions and the high-yield spread, TED spread, or the $\mathrm{P} / \mathrm{D}$ ratio.

The crudeness of these proxies means they cannot eliminate the possible importance of access, experience, and timing but they do motivate us to consider alternative explanations for the superior returns.

\section{III.3.2 Conjecture of Better Information Processing for Larger PE investors}

We conjecture another possibility, that the scale of investment brings with it a superior ability for larger investors, relative to smaller investors, to manage the information asymmetries that need to be bridged for successful PE investing. These asymmetries include the ability to assess the attractiveness of portfolio investments for direct investing and the capabilities of and contracts offered by different fund managers asking for LP investments. The importance of bridging asymmetries is widely recognized (e.g. Lerner and Schoar (2004), Lerner, Schoar, and Wongsunwai (2007), Kaplan and Stromberg (2009), as is the importance of understanding opaque and complex contracts (Metrick and Yasuda (2010), Phalippou (2009)).

One rationale for such an 'information processing' advantage for larger PE investors is simply that scale is associated with more investments, each of which generates information not only about the specific fund investment but also about prospects for PE more generally allowing for a better evaluation of alternatives. As important, larger PE investors might have greater 
information processing ability than smaller PE investors. Larger investors need to attract and retain larger teams to manage their more extensive portfolios, and individuals with ability may be more willing to work for larger investors. Larger PE investors are most likely to acquire more information and more processing ability if they engage in internal investing which requires more people with greater ability.

Further evidence supportive of this conjecture is provided by DaRin and Phalippou (2014). To look into the black box of PE investing, they surveyed limited partners and asked about their staffing, and their screening, contracting and monitoring efforts. The one variable with consistent predictive power, more so than investor type or experience, was the scale of $\mathrm{PE}$ investing. They find that larger PE investors had better staffing, with fewer funds and dollars per professional, and a focus on PE rather than other alternatives. They find that larger investors spend more time screening new funds and reinvestment decisions, being more willing to use their own data to evaluate fund returns. They find that larger plans also are more likely to negotiate terms, and to expend monitoring effort, visiting portfolio companies, taking seats on funds' advisory boards, and having better attendance records on such boards.

This 'information processing hypothesis' is a conjecture as our data contains no direct measures of information processing. This conjecture though offers the simplest explanation for two facts. First, it provides a simple explanation for the significant differences in approaches to intermediation documented above. With superior information processing ability, larger PE investors can dis-intermediate funds and focus away from fund-of-funds to fund investing and, for the largest, on direct investing.

Second, as we show in further tests on gross returns in Table VI, the conjecture of superior information processing provides a simple explanation for our finding that larger investors have superior gross returns in all three approaches to PE investing of LP investing, fund-of-fund investing and direct investing. In (5-6) we repeat our prior analysis of the overall 
PE portfolios focusing just on LP investments, with the first regression without controls for access and experience and the second with those controls. In (7-8) we do the same focusing on fund-of-fund investments. In (9) we explore returns to internal investing. Looking at the coefficient on lag log holdings in (6), (8) and (9), we find that even with proxies for access and experience, scale of investing remains statistically significant and economically important across all three styles. Our proxy for access is more important with LP investing (6) than fund-of-fund investing (8), and including these proxies reduces the estimated impact of scale for LP investing in (6) by close to $20 \%$. The positive and significant coefficient on lag holdings for fund-of-fund investing (8) is particularly important for the information processing conjecture as there is no clear alternative hypotheses to explain this result.

Finally, the information processing conjecture suggests a channel through which larger investors generate positive spillovers by harvesting information from one approach to $\mathrm{PE}$ investing (e.g. internal) and using it in another form (e.g. fund investing). It suggests the information spillover will be stronger from internal to external investing than the converse as internal investing requires developing more capabilities. It leaves open the question whether it is access to more information or information processing capability that is more important.

In Table VII we explore these three implications/questions. First we test whether plans that invest internally generate gains from this internal investing for their future returns in fund investing. The dependent variable in (1-2) is gross and net returns for externally managed holdings (LPs and fund-of-funds) with the standard controls for domicile, corporate status, and year fixed effects. To capture the potential impact of past internal investing and past ability in internal investing for performance of their fund portfolios, we include an indicator variable if plans in the prior period had more than a trivial amount (we use $5 \%$ of all PE investment) of internal investment, and another indicator variable if based on previous history there was 
evidence plans had top quartile internal teams. ${ }^{24}$ To explore whether the strength of the spillover is different from external to internal investing we repeat these regressions using internal investing returns as the dependent variable in (3-4) and testing if past skill in external investing translates into better future performance in internal investing.

In (1-2) we find a positive coefficient on the past internal investing dummy, but this is not significant. We find further that lagged top quartile internal return dummy is both positive and statistically significant in both specifications. This suggests that while information alone may be helpful to generate positive spillovers it is not enough to take advantage of information gained from internal investing, plans must have superior ability in that investing. In (3-4) we report results from the converse test of past returns to external investing on current returns to internal investing. We find a positive but much smaller and insignificant coefficient on lag top quartile external dummy in both specifications, suggesting the greatest spillovers come from investing in internal investing capabilities.

\section{III.4 Relating Results to the Literature}

These results are complementary to the existing literature. The survey by DaRin and Phalippou (2014) provides evidence consistent with the conjecture that PE scale captures differences in the ability to bridge information asymmetries in PE investing, and suggests the mechanisms at work. Fang, Ivashina and Lerner (2014) likewise document the importance of internal investing to large plans, while providing further insight into the relative importance of different approaches to internal investing to large investors in their study of performance of 7 large investors. Andonov et al (2014) also use the CEM data and provide evidence that the scale benefits that we document here extend to real estate as well. The results in Andonov, Bauer, and Cremers (2012) do not relate to this study as they are at the plan-level or alternatives level,

\footnotetext{
${ }^{24}$ To identify top quartile internal teams we computed the percentile of internal gross returns in the overall return distribution (internal or external) over the previous three years. 'Top quartile' performers are those for which the average of the percentiles exceeds 75 .
} 
but never focus on the PE-level, are restricted to US plans in the CEM data, and use a different methodology. ${ }^{25}$

\section{Conclusions}

Using data on PE investments of defined benefit pension plans we find that investors with substantial PE holdings outperform investors with smaller PE holdings. A one standard deviation increase in PE holdings of approximately $\$ 1.9$ billion increases returns by $4 \%$. When holdings of PE increase from small plan to large plan median, net returns improve by up to $7.4 \%$ per year. All in all, investment scale is a first-order determinant of investor performance in PE, and this result persists in the more competitive PE industry in the 2000s.

We seek to explain this result by appealing to economic explanations for the impact of scale on performance. We find that cost advantages for larger plans are important contributors to the superior performance, accounting for up to one third of the performance gain. Our tests also highlight a new fact of disintermediation by large investors with substantial internal investment at substantially lower costs. Further, we document superior gross returns for larger investors in PE consistent with superior information or skill for large investors.

Our findings show potential benefits for a range of asset owners/managers that can make substantial investments to PE. Besides pension plans, such investors include sovereign wealth funds and large endowments. Fund-of-funds should be also capable of benefitting from such scale advantages, but likely to a lesser degree as they are unlikely to engage in direct investing.

The weaker returns to investors with limited PE holdings bring into question the desirability or sustainability of such investments for plans with a limited ability to commit to a

\footnotetext{
${ }^{25}$ Rather than use returns net of an appropriate benchmark, or use net returns with academic factors, these authors use both simultaneously. Doing so changes little in our results, but with no economic rationale for this approach, we do not adopt it. Moreover, in their factor regressions, these authors regress individual fund returns on six factors plus an intercept. Working with the same data as we, they can only use a fraction of the data for such an estimation (the median plan has 4 annual observations; only $25 \%$ of plans have more than 10 observations). For our factor tests we construct portfolios of plans and limit factors to those most commonly used to preserve degrees of freedom.
} 
PE program. Combining our finding of a $4 \%$ impact of a one standard deviation change in holdings with findings in other papers of average performance over an equity index of at most 3$4 \%$ a year, plans with limited PE investments may underperform relative to equities. To justify such investments they would have to benefit significantly from enhanced diversification from PE. One alternative would be to stay away from the asset class; as we show in Table I, this is indeed the norm amongst plans with fewer plan assets. Another alternative is for such investors to seek asset management vehicles with more capacity for scale. We note that in a number of countries, including the United Kingdom, the Netherlands, and Canada, governments as plan sponsors of some of the sub-scale investors are considering pension reforms that promote reallocation of pension contributions to more scaled pooled asset management vehicles, in part motivated by the possibilities of capturing such returns. ${ }^{26}$ To the extent that investors do alter their approach to $\mathrm{PE}$, this has important implications for funds more generally.

Finally, we conjecture that a possible explanation for gains to scale comes from superior information processing capability of larger PE investors and present suggestive evidence consistent with the conjecture. This conjecture points also to the potential importance of differences across plans in their ability to attract and retain talent to oversee and run PE portfolios, and of governance structure. We leave these questions for future research.

\footnotetext{
${ }^{26}$ In the UK, the National Employment Savings Trust (NEST) presents one effort to create a scaled investment vehicle. In the Netherlands and Canada there are efforts to allow existing large pension plans to open themselves up to other members, and large plans that have moved to take advantage of this opportunity include APG (Netherlands), Ontario Teachers Pension Plan (Canada) and OMERS (Canada). See, for example, http://www.omers.com/About_OMERS/OMERS_Investment_Management_Services_available_to_third_parties.htm). In Ontario, Canada, the provincial government is considering proposals to force smaller plans into mega plans to capture such advantages (The Morneau Report, "Facilitating Pooled Asset Management for Ontario's Public Sector Institutions," October 2012).
} 


\section{References}

Andonov, Aleksandar, Rob M.M.J. Bauer, and Martijn K.J. Cremers, 2014, "Can Large Pension Funds Beat the Market? Asset Allocation, Market Timing, Security Selection and the Limits of Liquidity," working paper, Maastricht University.

Andonov, Aleksandar, Piet Eicholz, and Nils Kok, 2014, "Intermediated Investment Management in Private Markets: Evidence from Pension Fund Investments in Real Estate," working paper, Maastricht University.

Bauer, Rob M.M.J., Martijn K.J. Cremers, and Rik G. P. Frehen, 2011, "Pension Fund Performance and Costs: Small is Beautiful," working paper, Maastricht University.

Chen, Joseph S., Harrison G. Hong, Ming Huang, and Jeffrey D. Kubik, 2004, "Does Fund Size Erode Mutual Fund Performance? The Role of Liquidity and Organization," American Economic Review, Volume 95, No. 5, 1276-1302.

Cochrane, John, 2005, "The Risk and Return of Venture Capital," Journal of Financial Economics, Vol. 75, No. 1, 3-52.

DaRin, Marco and Ludovic Phalippou," 2014, "There is Something Special about Large Investors: Evidence from a Survey of Private Equity Limited Partners," ECGI Working Paper Series in Finance, No. 408.

Drissen, Joost, Tse-Chun Lin, and Ludovic Phalippou, 2011, "A New Method to Estimate Risk and Return of Non-traded Assets from Cash Flows: The Case of Private Equity Funds," Journal of Financial and Quantitative Analysis, forthcoming.

Dyck, Alexander, Karl Lins and Lukasz Pomorski, 2013, "Does Active Management Pay? New International Evidence," Review of Asset Pricing Studies, Issue 3, pp 200-228.

Fang, Lily, Victoria Ivashina, and Josh Lerner, 2014, "The Disintermediation of Financial Markets: Direct Investing in Private Equity," Journal of Financial Economics, forthcoming.

Franzoni, Francesco A., Eric Nowak, and Ludovic Phalippou, 2011, "Private Equity Performance and Liquidity Risk," Journal of Finance, forthcoming.

French, Kenneth R., 2008, "Presidential Address: The Cost of Active Investing," Journal of Finance, Volume 63, No. 4, 1537-1573.

Harris, Robert, Tim Jenkinson, and Steven Kaplan, 2014, "Private Equity Performance: What Do We Know?," Journal of Finance, 69:5, 1851-1882.

Jegadeesh, Narasimhan, Roman Kraussl, and Joshua Pollet, 2011, "Risk and Expected Returns of Private Equity Investments: Evidence Based on Market Prices," working paper.

Kaplan, Steven and Antoinette Schoar, 2005, "Private Equity Performance: Returns, Persistence and Capital Flows," Journal of Finance, Vol. 60, No. 4, 1791-1823.

Kaplan, Steven and Per Stromberg, 2009, "Leveraged Buyouts and Private Equity," Journal of Economic Perspectives, vol. 23(1), 121-146. 
Korteweg, Arthur and Morten Sorensen, 2010, "Risk and Return of Venture Capital-Backed Entrepreneurial Companies," Review of Financial Studies, Vol. 23, No. 10, 3738-3772.

Lerner, Josh and Antoinette Schoar, 2004, "The Illiquidity Puzzle: Evidence from Private Equity Partnerships," Journal of Financial Economics, Vol. 72, No. 2, 3-40.

Lerner, Josh, Antoinette Schoar, and Wan Wongsunwai, 2007, "Smart Institutions, Foolish Choices?: The Limited Partner Performance Puzzle," Journal of Finance, Vol 62, No. 2, 731-764.

Lerner, Josh, Antoinette Schoar, and Jialan Wang, 2008, "Secrets of the Academy: The Drivers of University Endowment Success," Journal of Economic Perspectives, Volume 22, 207-222.

Metrick, Andrew and Ayako Yasuda, 2010, "The Economics of Private Equity Funds," Review of Financial Studies, Volume 23, No. 6, 2303-2341.

Phalippou, Ludovic, 2009, "Beware of Venturing into Private Equity," Journal of Economic Perspectives, Volume 23, No. 1, 147-166.

Phalippou, Ludovic and Oliver Gottschalg, 2009, "The performance of private equity funds," Review of Financial Studies, Volume 22, No. 4, pp. 1747-1776.

Petersen, Mitchell A., 2009, "Estimating Standard Errors in Finance Panel Data Sets: Comparing Approaches," Review of Financial Studies, Volume 22, No. 1, 435-480."

Robinson, David and Berk Sensoy, 2012, "Cyclicality, Performance Measurement, and Cash Flow Liquidity in Private Equity," working paper, Duke University.

Sensoy, Berk, Yingdi Wang, and Michael Weisbach, 2014, "Limited Partner Performance and the Maturing of the Private Equity Industry," Journal of Financial Economics, Volume 112, $320-343$.

Stein, Jeremy, 2002, "Information Production and Capital Allocation: Decentralized vs. Hierarchical Firms," Journal of Finance, Volume 57, Issue 5, 1891-1921. 
Figure 1. Shape of the PE scale-performance relationship. This figure presents fitted values from regressions of net $\mathrm{PE}$ returns on scale in PE investing, controlling for corporate plan indicator, non-US plan indicator, and year fixed effects, as in regression (3) in Table II. In the linear, quadratic and cubic specifications, scale is measured as the log of the prior year's holdings in PE (in \$ million). In the fitted quintile returns, dummy variables are introduced for size quintiles based on prior year's PE holdings.

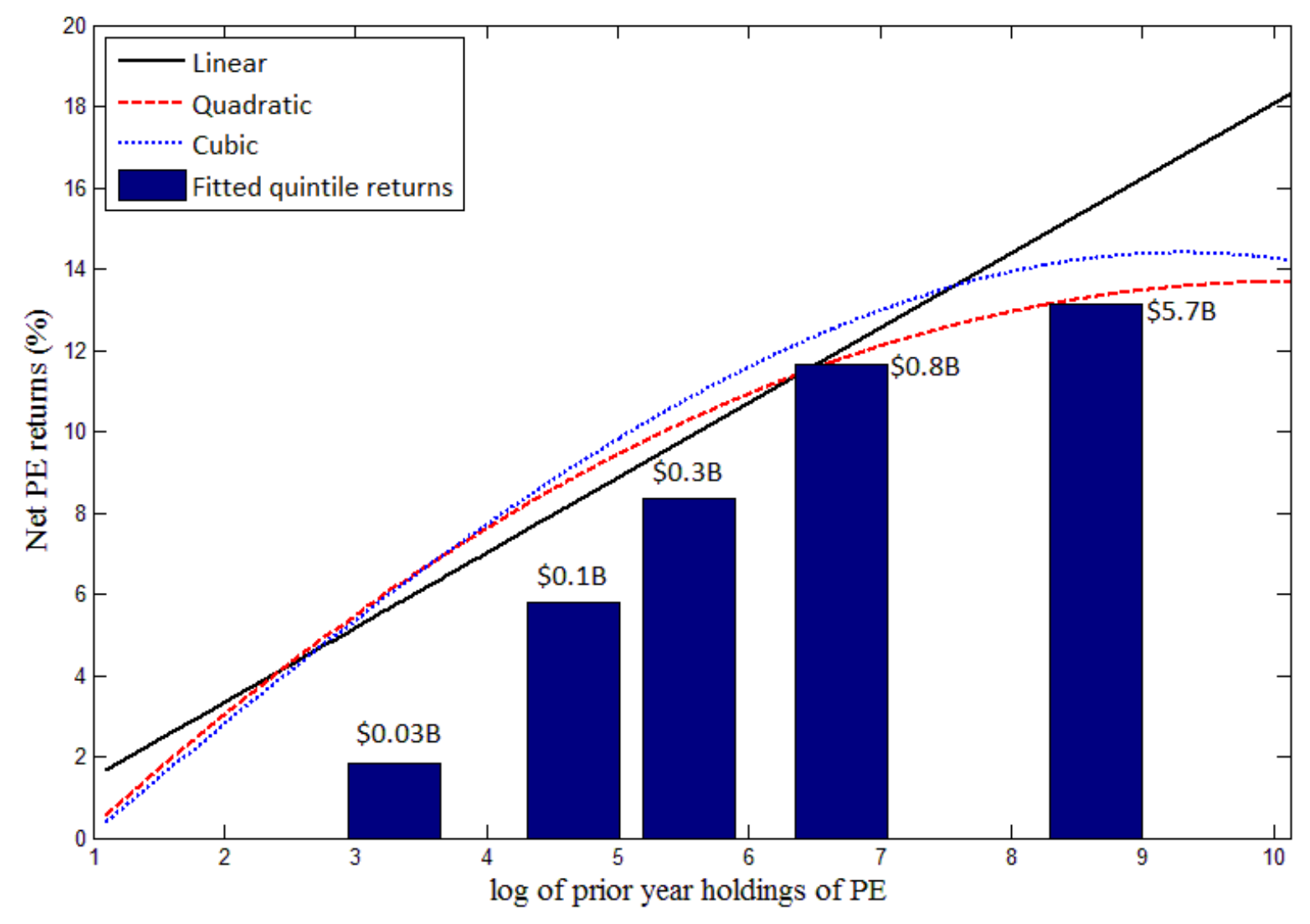


Table I: Summary statistics of the CEM database. The table presents overall plan characteristics and key performance measures for PE holdings. The statistics are time series averages, with plans sorted into size quintiles defined in each year over 1991-2009 based on lagged holdings. S\&P500 returns are lagged one quarter to reflect an expected time lag in PE reporting. Benchmark returns are plan-specific PE benchmark returns. The last section of the table presents performance data in the most recent sample years of 2007-2009. Gross and net returns are reported in percentages, costs in basis points.

\begin{tabular}{|c|c|c|c|c|c|c|c|c|c|}
\hline & Mean & St.dev. & 25 th $\%$ & Median & 75 th $\%$ & Max & & & \\
\hline \multicolumn{10}{|l|}{ Sample and plan characteristics } \\
\hline \# plans/year & 270 & 71 & 269 & 286 & 298 & 368 & & & \\
\hline \multirow[t]{3}{*}{ Total dollars (USD trillion)/year } & 2.89 & 1.39 & 1.75 & 2.83 & 3.88 & 5.46 & & & \\
\hline & Mean & Median & IQR & $\begin{array}{c}\mathrm{Q} 1 \\
\text { (small) }\end{array}$ & Q2 & Q3 & Q4 & $\begin{array}{c}\text { Q5 } \\
\text { (large) }\end{array}$ & $\begin{array}{l}\text { Large } \\
\text { minus } \\
\text { small }\end{array}$ \\
\hline & & & & \multicolumn{6}{|c|}{ Plans sorted on overall plan size } \\
\hline Overall plan size $(\$ B)$ & 10.26 & 2.47 & 6.89 & 0.42 & 1.22 & 2.55 & 6.45 & 41.10 & 40.68 \\
\hline$\%$ non-US & $43 \%$ & & & $75 \%$ & $48 \%$ & $37 \%$ & $25 \%$ & $29 \%$ & $-46 \%$ \\
\hline$\%$ corporate & $55 \%$ & & & $65 \%$ & $60 \%$ & $65 \%$ & $52 \%$ & $30 \%$ & $-35 \%$ \\
\hline$\%$ liabilities related to retirees & 46 & 46 & 15 & 48 & 46 & 46 & 47 & 50 & 2 \\
\hline$\%$ with any $\mathrm{PE}$ & $53 \%$ & & & $20 \%$ & $42 \%$ & $59 \%$ & $69 \%$ & $84 \%$ & $64 \%$ \\
\hline \multicolumn{10}{|l|}{ Private Equity } \\
\hline & \multicolumn{3}{|c|}{$1991-2009$} & \multicolumn{6}{|c|}{ Plans sorted on lag PE holdings } \\
\hline average holdings/plan $(\$ M)$ & 705.3 & 114.0 & 459.4 & 10.4 & 44.6 & 126.7 & 398.2 & 2999.3 & 2988.9 \\
\hline Gross returns & 12.3 & 10.5 & 20.4 & 7.4 & 9.3 & 12.1 & 15.2 & 16.2 & 8.8 \\
\hline Costs & 259 & 197 & 185 & 386 & 275 & 231 & 232 & 185 & -201 \\
\hline Net returns & 9.64 & 8.10 & 20.50 & 3.52 & 6.57 & 9.83 & 12.83 & 14.36 & 10.84 \\
\hline Net returns minus S\&P 500 & 2.61 & 1.07 & 20.50 & -3.51 & -0.46 & 2.80 & 5.80 & 7.33 & 10.84 \\
\hline Net returns minus benchmark & -1.66 & -2.53 & 21.74 & -7.13 & -4.12 & -1.71 & 0.92 & 2.52 & 9.65 \\
\hline & \multicolumn{3}{|c|}{ Only 2007-2009 } & \multicolumn{6}{|c|}{ Plans sorted on lag PE holdings, only 2007-2009 } \\
\hline average holdings/plan $(\$ M)$ & 1361.4 & 242.7 & 915.7 & 27.0 & 105.9 & 255.4 & 820.6 & 5666.3 & 5639.3 \\
\hline Gross returns & 3.4 & 3.3 & 13.9 & 2.1 & 4.1 & 0.4 & 4.9 & 5.5 & 3.4 \\
\hline Costs & 371 & 290 & 256 & 517 & 410 & 361 & 302 & 264 & -253 \\
\hline Net returns & -0.28 & -0.96 & 15.05 & -3.09 & 0.01 & -3.25 & 1.87 & 2.82 & 5.91 \\
\hline
\end{tabular}


Table II. Scale and net returns in private equity. The dependent variable is net returns (gross returns minus costs) on a plan's overall PE holdings (in (2), net return minus S\&P500 return lagged one quarter). The main independent variable is lag of log PE holdings. In (6) we use plans for which the ratio of holdings to assets used to compute fees is less than one. Regressions $(4,5,7,9)$ use data from indicated years. Regression (8) is estimated using FamaMacBeth method. Regressions are estimated with year and plan fixed effects, as indicated. Standard errors are clustered at the plan level and t-stats are reported in parentheses below the coefficient. ${ }^{* * *},{ }^{* *}$, and $*$ denote statistical significance at the $1 \%, 5 \%$, and $10 \%$ levels, respectively. Economic effects illustrate the implied change in PE net returns from a one standard deviation increase in log holdings, as well as moving from the median holdings of small plans (bottom quintile of plans sorted on overall size) to the median holdings of large plans (largest quintile).

\begin{tabular}{|c|c|c|c|c|c|c|c|c|c|c|}
\hline & (1) & $\begin{array}{c}\text { (2) } \\
\text { Net ret } \\
\text { minus } \\
\text { SP500 }\end{array}$ & $(3)$ & $\begin{array}{c}(4) \\
1990- \\
1999\end{array}$ & $\begin{array}{c}(5) \\
2000- \\
2009\end{array}$ & (6) & $\begin{array}{c}(7) \\
\text { Only } \\
2001-9\end{array}$ & $\begin{array}{c}\text { (8) } \\
\text { Fama- } \\
\text { MacBeth }\end{array}$ & $\begin{array}{c}(9) \\
\text { Exclude } \\
1993-5, \\
1997-9 \\
2006-8 \\
\end{array}$ & $(10)$ \\
\hline lag log PE holdings & $\begin{array}{c}1.031^{* * *} \\
(3.92)\end{array}$ & $\begin{array}{c}1.739^{* * *} \\
(6.88)\end{array}$ & $\begin{array}{c}1.836^{* * *} \\
(6.84)\end{array}$ & $\begin{array}{c}2.295^{* * *} \\
(4.55)\end{array}$ & $\begin{array}{c}1.604^{* * *} \\
(4.68)\end{array}$ & $\begin{array}{c}2.018^{* * *} \\
(8.10)\end{array}$ & $\begin{array}{c}0.993^{* * *} \\
(3.14)\end{array}$ & $\begin{array}{c}1.685^{* * *} \\
(3.46)\end{array}$ & $\begin{array}{c}1.538^{* * *} \\
(4.19)\end{array}$ & $\begin{array}{c}2.946^{* * *} \\
(2.67)\end{array}$ \\
\hline $\begin{array}{l}\text { ratio holdings/assets } \\
\text { used to compute fees }\end{array}$ & & & & & & $\begin{array}{c}1.984^{* *} \\
(2.09)\end{array}$ & & & & \\
\hline $\begin{array}{l}\text { lag log size * (Rmega - } \\
\text { Rsmall) }\end{array}$ & & & & & & & $\begin{array}{c}0.106^{* * *} \\
(4.12)\end{array}$ & & & \\
\hline Corporate plan dummy & $\begin{array}{c}3.609^{* * *} \\
(3.14)\end{array}$ & $\begin{array}{l}2.057^{*} \\
(1.87)\end{array}$ & $\begin{array}{c}2.475^{* *} \\
(2.29)\end{array}$ & $\begin{array}{l}1.100 \\
(0.59)\end{array}$ & $\begin{array}{c}3.356^{* *} \\
(2.56)\end{array}$ & $\begin{array}{c}2.215^{* *} \\
(2.01)\end{array}$ & $\begin{array}{c}2.394^{* *} \\
(2.09)\end{array}$ & $\begin{array}{l}1.738 \\
(1.38)\end{array}$ & $\begin{array}{l}1.799 \\
(1.19)\end{array}$ & \\
\hline Non-US plan dummy & $\begin{array}{c}-3.272^{* * *} \\
(-2.65)\end{array}$ & $\begin{array}{c}-3.164^{* * *} \\
(-2.70)\end{array}$ & $\begin{array}{c}-2.356^{* *} \\
(-1.99)\end{array}$ & $\begin{array}{c}-6.038^{* * *} \\
(-2.85)\end{array}$ & $\begin{array}{l}-0.117 \\
(-0.08)\end{array}$ & $\begin{array}{l}-1.676 \\
(-1.41)\end{array}$ & $\begin{array}{l}-0.566 \\
(-0.44)\end{array}$ & $\begin{array}{l}-3.224^{*} \\
(-1.83)\end{array}$ & $\begin{array}{l}-1.193 \\
(-0.67)\end{array}$ & \\
\hline Observations & 2127 & 2127 & 2127 & 760 & 1367 & 1941 & 1,250 & 2127 & 1,103 & 2127 \\
\hline R-squared & 0.018 & 0.033 & 0.303 & 0.162 & 0.319 & 0.322 & 0.366 & 0.015 & 0.318 & 0.434 \\
\hline Year FE & $\mathrm{NO}$ & $\mathrm{NO}$ & YES & YES & YES & YES & YES & $\mathrm{N} / \mathrm{A}$ & YES & YES \\
\hline Fund FE & $\mathrm{NO}$ & $\mathrm{NO}$ & $\mathrm{NO}$ & $\mathrm{NO}$ & $\mathrm{NO}$ & $\mathrm{NO}$ & $\mathrm{NO}$ & $\mathrm{N} / \mathrm{A}$ & $\mathrm{NO}$ & YES \\
\hline \multicolumn{11}{|l|}{ Economic effects } \\
\hline One st. deviation change & 2.25 & 3.80 & 4.01 & 5.01 & 3.50 & 4.40 & 2.17 & 3.68 & 3.35 & 6.44 \\
\hline Q1 to Q5 change & 4.15 & 6.99 & 7.38 & 9.23 & 6.45 & 8.09 & 3.99 & 6.78 & 6.18 & $11.85^{+}$ \\
\hline
\end{tabular}

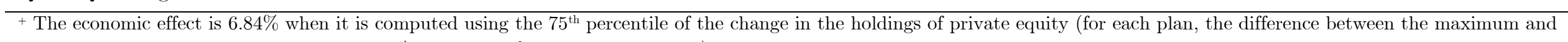
minimum allocation is computed, and the $75^{\text {th }}$ percentile of that variable is used). 
Table III: Return differences and risk. In this table we construct a spread portfolio on net returns that is long in large PE investors' PE positions (top size quintile based on lagged PE holdings) and short in small investors' PE positions (bottom quintile) to explore if there is alpha after controlling for exposures to asset pricing risk factors. Risk factors include returns on CRSP, Russell 2000, and Russell 2000 Value indexes, and the Fama-French size and value factors. Model (5) includes as an additional variable the difference of returns between mega and small PE funds, obtained from Preqin. All risk-factor returns are lagged by one quarter relative to private equity returns, and expressed in percent per year.

\begin{tabular}{|c|c|c|c|c|c|}
\hline & $(1)$ & $(2)$ & $(3)$ & $(4)$ & $(5)$ \\
\hline Alpha & $\begin{array}{c}8.01^{* * *} \\
(3.05)\end{array}$ & $\begin{array}{c}9.36^{* * *} \\
(3.16)\end{array}$ & $\begin{array}{c}10.34^{* *} \\
(2.72)\end{array}$ & $\begin{array}{c}11.05^{* * *} \\
(3.44)\end{array}$ & $\begin{array}{l}7.72^{\text {** }} \\
(2.90)\end{array}$ \\
\hline CRSP market & $\begin{array}{c}0.43^{* * *} \\
(2.99)\end{array}$ & & & $\begin{array}{c}0.29 \\
(1.66)\end{array}$ & $\begin{array}{l}0.42^{*} \\
(2.34)\end{array}$ \\
\hline Russell 2000 & & $\begin{array}{c}0.25 \\
(1.64)\end{array}$ & & & \\
\hline Russell 2000 Value & & & $\begin{array}{c}0.36^{*} \\
(1.80)\end{array}$ & & \\
\hline SMB & & & & $\begin{array}{l}-0.30 \\
(-1.14)\end{array}$ & \\
\hline HML & & & & $\begin{array}{l}-0.26 \\
(-1.31)\end{array}$ & \\
\hline $\mathrm{R}_{\mathrm{mega}}-\mathrm{R}_{\text {small }}$ & & & & & $\begin{array}{c}0.01 \\
(0.02)\end{array}$ \\
\hline Observations & 19 & 19 & 14 & 19 & 9 \\
\hline R-squared & 0.345 & 0.136 & 0.212 & 0.444 & 0.625 \\
\hline
\end{tabular}


Table IV: Costs and scale-based differences in PE investment approaches. Panel A illustrates costs (in basis points per year) of different PE investment approaches (external fund-of-funds, external LP investments, internal investments). Panel B shows differences across PE holdings size quintiles in the likelihood of having a given investment approach, as well as the fraction of overall PE holdings in that approach. The table presents the time series average based on annual results using the last three sample years (2007-2009).

Panel A: Costs (bps) by investment approach

\begin{tabular}{lccccccc} 
& \#obs & Mean & St.dev. & 25th \% & Median & 75 th \% & IQR \\
\hline & & & & & & & \\
Funds of funds & 329 & 694 & 1518 & 290 & 443 & 653 & 363 \\
External & 502 & 351 & 509 & 168 & 240 & 362 & 194 \\
Internal & 75 & 35 & 50 & 2 & 19 & 44 & 43 \\
\hline
\end{tabular}

Panel B: Reliance on different PE investment approaches

\begin{tabular}{lrrrrr} 
PE holdings quintile: & Q1 & Q2 & Q3 & Q4 & Q5 \\
\hline \% with any internal holdings & $6 \%$ & $3 \%$ & $5 \%$ & $7 \%$ & $24 \%$ \\
\% overall assets in internal & $2 \%$ & $1 \%$ & $0 \%$ & $2 \%$ & $10 \%$ \\
\hline \% with fund-of-fund holdings & $52 \%$ & $51 \%$ & $55 \%$ & $48 \%$ & $26 \%$ \\
\% overall assets in FOFs & $48 \%$ & $37 \%$ & $35 \%$ & $22 \%$ & $11 \%$ \\
\hline
\end{tabular}


Table V: Cost savings from investment approaches and negotiating power. The dependent variable is costs in bps. The main independent variable is lag log PE holdings for a given investment approach. Model (1) only includes holdings invested using via fund-of-funds. Model (2) only uses LP investments. Model (3) only uses direct investments made by plan managers. All regressions use year fixed effects. Standard errors are clustered at the plan level and t-stats are reported in parentheses below the coefficient. ${ }^{* * *}$, ${ }^{* *}$, and ${ }^{*}$ denote statistical significance at the $1 \%, 5 \%$, and $10 \%$ levels, respectively. Economic effects illustrate the implied change in costs in bps from a one standard deviation increase in log holdings in that investment approach, as well as moving from the median holdings of small plans (bottom quintile of plans sorted on overall size) to the median holdings of large plans (largest quintile).

\begin{tabular}{|c|c|c|c|c|c|c|}
\hline Investment approach & $\begin{array}{c}\text { (1) } \\
\text { Fund-of-funds }\end{array}$ & $\begin{array}{l}(2) \\
\text { LP }\end{array}$ & $\begin{array}{c}(3) \\
\text { Internal } \\
\end{array}$ & $\begin{array}{l}(4) \\
\text { All } \\
\end{array}$ & $\begin{array}{l}(5) \\
\text { All } \\
\end{array}$ & $\begin{array}{l}6) \\
\text { All } \\
\end{array}$ \\
\hline lag log holdings & $\begin{array}{l}-90.6^{* * *} \\
(-3.47)\end{array}$ & $\begin{array}{c}-23.8^{* * *} \\
(-3.98)\end{array}$ & $\begin{array}{c}-0.5 \\
(-0.24)\end{array}$ & & $\begin{array}{l}-44.7^{* * *} \\
(-6.32)\end{array}$ & $\begin{array}{l}-36.0 * * * \\
(-5.26)\end{array}$ \\
\hline Holdings in Q1 & & & & $\begin{array}{c}280.6^{* * *} \\
(6.32)\end{array}$ & & \\
\hline Holdings in Q2 & & & & $\begin{array}{c}143.6^{* * *} \\
(5.07)\end{array}$ & & \\
\hline Holdings in Q3 & & & & $\begin{array}{c}65.4^{* * *} \\
(3.15)\end{array}$ & & \\
\hline Holdings in Q4 & & & & $\begin{array}{c}62.0^{* * *} \\
(3.39)\end{array}$ & & \\
\hline$\%$ in fund-of-funds(FOF) & & & & & & $\begin{array}{c}367.5^{\text {*** }} \\
(8.83)\end{array}$ \\
\hline$\%$ in LP & & & & & & $\begin{array}{c}149.7^{* * *} \\
(4.87)\end{array}$ \\
\hline Corporate plan dummy & $\begin{array}{c}-167.7^{* *} \\
(-2.54)\end{array}$ & $\begin{array}{c}-118.4^{* * *} \\
(-6.21)\end{array}$ & $\begin{array}{c}-5.6 \\
(-0.48)\end{array}$ & $\begin{array}{c}-121.2^{* * *} \\
(-5.01)\end{array}$ & $\begin{array}{c}-120.6^{* * *} \\
(-4.88)\end{array}$ & $\begin{array}{c}-107.2^{* * *} \\
(-4.81)\end{array}$ \\
\hline Non-US plan dummy & $\begin{array}{l}71.8 \\
(0.80)\end{array}$ & $\begin{array}{l}-38.8^{*} \\
(-1.73)\end{array}$ & $\begin{array}{l}13.3 \\
(1.41)\end{array}$ & $\begin{array}{l}-80.7^{* * *} \\
(-2.99)\end{array}$ & $\begin{array}{c}-77.5^{* * *} \\
(-2.75)\end{array}$ & $\begin{array}{c}-28.1 \\
(-0.95)\end{array}$ \\
\hline Observations & 479 & 1695 & 302 & 2163 & 2163 & 2163 \\
\hline R-squared & 0.234 & 0.140 & 0.051 & 0.158 & 0.161 & 0.212 \\
\hline \multicolumn{7}{|l|}{ Economic effects } \\
\hline One standard deviation change & -174 & -48 & -1 & & -98 & -79 \\
\hline Q1 to Q5 change & -211 & -112 & -2 & & -180 & -145 \\
\hline
\end{tabular}


Table VI: Explaining gross returns. The dependent variable is gross returns (in percentage per year) on holdings of PE for the investment approach indicated in the top row. Regressions include controls for corporate status, non-US dummy, year and plan fixed effects, as indicated. Standard errors are clustered at the plan level and t-stats are reported in parentheses below the coefficient. ***, **, and * denote statistical significance at the $1 \%, 5 \%$, and $10 \%$ levels, respectively. Economic effects illustrate the implied change in gross returns from a one standard deviation increase in log holdings in that investment approach, as well as moving from the median holdings of small plans (bottom quintile of plans sorted on overall size) to the median holdings of large plans (largest quintile).

\begin{tabular}{|c|c|c|c|c|c|c|c|c|c|}
\hline & (1) & (2) & (3) & (4) & $(5)$ & (6) & (7) & $(8)$ & (9) \\
\hline Subset of PE holdings: & \multicolumn{4}{|c|}{ Overall } & \multicolumn{2}{|c|}{ LP holdings } & \multicolumn{2}{|c|}{ Fund-of-funds holdings } & Internal \\
\hline lag log holdings & $\begin{array}{c}1.370^{* * *} \\
(5.34)\end{array}$ & $\begin{array}{c}1.348^{* * *} \\
(4.92)\end{array}$ & $\begin{array}{l}1.949 * \\
(1.80)\end{array}$ & $\begin{array}{c}1.234^{* * *} \\
(4.62)\end{array}$ & $\begin{array}{c}1.180^{* * *} \\
(4.25)\end{array}$ & $\begin{array}{c}0.998^{* * *} \\
(3.43)\end{array}$ & $\begin{array}{c}1.833^{* * *} \\
(4.43)\end{array}$ & $\begin{array}{c}1.956^{* * *} \\
(4.84)\end{array}$ & $\begin{array}{c}2.385^{* * *} \\
(2.76)\end{array}$ \\
\hline$\%$ in fund-of-funds & & $\begin{array}{l}0.591 \\
(0.42)\end{array}$ & & & & & & & \\
\hline$\%$ internally managed & & $\begin{array}{l}2.206 \\
(0.70)\end{array}$ & & & & & & & \\
\hline Lag returns in top quartile & & & & $\begin{array}{c}5.981^{* * *} \\
(4.94)\end{array}$ & & $\begin{array}{c}5.360^{* * *} \\
(4.52)\end{array}$ & & $\begin{array}{l}0.876 \\
(0.40)\end{array}$ & \\
\hline$\%$ past years with $\mathrm{PE}$ & & & & $\begin{array}{l}2.926 \\
(1.19)\end{array}$ & & $\begin{array}{l}4.473 \\
(1.64)\end{array}$ & & $\begin{array}{l}-2.169 \\
(-0.52)\end{array}$ & \\
\hline lag log overall plan size & & & & & & & & & \\
\hline Observations & 2,131 & 2131 & 2,131 & 2,109 & 1,695 & 1,695 & 410 & 365 & 302 \\
\hline R-squared & 0.291 & 0.292 & 0.418 & 0.305 & 0.309 & 0.321 & 0.490 & 0.494 & 0.175 \\
\hline Corporate and Non-US controls & YES & YES & YES & YES & YES & YES & YES & YES & YES \\
\hline Year FE & YES & YES & YES & YES & YES & YES & YES & YES & YES \\
\hline Plan FE & NO & NO & YES & NO & $\mathrm{NO}$ & NO & NO & NO & NO \\
\hline Economic effects & & & & & & & & & \\
\hline One standard deviation change & 2.99 & 2.94 & 4.26 & 2.70 & 2.36 & 1.99 & 3.51 & 3.75 & 5.41 \\
\hline Q1 to Q5 change & 5.51 & 5.42 & 7.84 & 4.96 & 5.54 & 4.68 & 4.27 & 4.56 & 10.28 \\
\hline
\end{tabular}


Table VII. Spillovers between internal investing and performance of externally managed PE investments. The dependent variable is gross and net returns on external LP positions (including both fund-of-funds and LP investment approaches) in (1) and (2), respectively, and gross and net returns on internal holdings in (3) and (4), respectively. The main independent variables are an internal holdings indicator (taking the value one whenever a plan manages at least $5 \%$ of its PE holdings internally), top quartile internal indicator (taking the value one whenever a plan achieves top quartile performance on its internal holdings), and a similar top quartile indicator for external holdings. To identify top quartile plans, we compute the percentile of internal performance in the overall performance distribution (internal or external) based on three previous years of data. All regressions are estimated with year fixed effects. Standard errors are clustered at the plan level and tstats are reported in parentheses below the coefficient. ${ }^{* * *},{ }^{* *}$, and $*$ denote statistical significance at the $1 \%, 5 \%$, and $10 \%$ levels, respectively.

\begin{tabular}{|c|c|c|c|c|}
\hline \multirow[b]{2}{*}{ Dependent variable } & \multicolumn{2}{|c|}{$\begin{array}{c}(1) \\
\text { Performance in LP positions }\end{array}$} & \multicolumn{2}{|c|}{$\begin{array}{c}(3) \\
\text { Performance in internal holdings }\end{array}$} \\
\hline & $\begin{array}{l}\text { Performance i } \\
\text { Gross returns }\end{array}$ & $\begin{array}{l}\text { LP positions } \\
\text { Net returns } \\
\end{array}$ & $\begin{array}{r}\text { Performance in } \\
\text { Gross returns }\end{array}$ & $\begin{array}{l}\text { ernal holdings } \\
\text { Net returns }\end{array}$ \\
\hline has any internal & $\begin{array}{l}1.033 \\
(0.67)\end{array}$ & $\begin{array}{l}0.248 \\
(0.16)\end{array}$ & & \\
\hline $\begin{array}{l}\text { lag top quartile internal } \\
\text { (based on prior three years) }\end{array}$ & $\begin{array}{c}6.010^{* *} \\
(2.21)\end{array}$ & $\begin{array}{c}5.891^{* *} \\
(2.03)\end{array}$ & & \\
\hline $\begin{array}{l}\text { lag top quartile external } \\
\text { (based on prior three years) }\end{array}$ & & & $\begin{array}{l}0.430 \\
(0.09)\end{array}$ & $\begin{array}{l}0.399 \\
(0.08)\end{array}$ \\
\hline lag log external holdings & $\begin{array}{c}1.214^{* * *} \\
(4.74)\end{array}$ & $\begin{array}{c}1.680^{* * *} \\
(6.19)\end{array}$ & & \\
\hline lag log external holdings & & & $\begin{array}{c}2.381^{* * *} \\
(2.75)\end{array}$ & $\begin{array}{c}2.386^{* * *} \\
(2.75)\end{array}$ \\
\hline Corporate plan dummy & $\begin{array}{c}0.672 \\
(0.64)\end{array}$ & $\begin{array}{c}1.847^{*} \\
(1.71)\end{array}$ & $\begin{array}{l}7.635^{*} \\
(1.74)\end{array}$ & $\begin{array}{l}\text { 7.691* } \\
(1.77)\end{array}$ \\
\hline Non-US plan dummy & $\begin{array}{c}-3.955^{* * *} \\
(-3.31)\end{array}$ & $\begin{array}{c}-3.374^{* * *} \\
(-2.74)\end{array}$ & $\begin{array}{l}-1.875 \\
(-0.57)\end{array}$ & $\begin{array}{l}-2.012 \\
(-0.61)\end{array}$ \\
\hline Observations & 2007 & 2007 & 302 & 302 \\
\hline R-squared & 0.322 & 0.336 & 0.195 & 0.176 \\
\hline
\end{tabular}

